\title{
Effects of phycoerythrin from Gracilaria lemaneiformis in proliferation and apoptosis of $\mathrm{SW480}$ cells
}

\author{
PEIZHEN LI ${ }^{1,2^{*}}$, JUN YING $^{1,2^{*}}$, QINGLI CHANG ${ }^{2}$, WEN ZHU $^{2}$, GUANGJIAN YANG $^{2}$, TENG XU $^{2}$, \\ HUIGUANG YI ${ }^{2}$, RUOWANG PAN ${ }^{3}$, ENYONG ZHANG ${ }^{3}$, XIAOFENG ZENG ${ }^{1,4}$, \\ CHUNXIA YAN $^{1}$, QIYU BAO ${ }^{2}$ and SHENGBIN LI ${ }^{1}$ \\ ${ }^{1}$ School of Forensic Medicine, Xi'an Jiaotong University, Xi'an, Shaanxi 710000; \\ ${ }^{2}$ School of Laboratory Medicine and Life Science/Institute of Biomedical Informatics, Wenzhou Medical University, \\ Wenzhou, Zhejiang $325035 ;{ }^{3} 118$ Hospital of PLA, Wenzhou, Zhejiang 325000 ; ${ }^{4}$ School of Forensic Medicine, \\ Kunming Medical University, Kunming, Yunnan 650000, P.R. China
}

Received April 28, 2016; Accepted August 29, 2016

DOI: $10.3892 /$ or.2016.5162

\begin{abstract}
We studied phycoerythrin (PE) in human SW480 tumor cells and the underlying molecular mechanisms of action. PE inhibited cell proliferation as evidenced by CCK-8 assay. The $\mathrm{IC}_{50}$ values of phycoerythrin were 48.2 and $27.4 \mu \mathrm{g} / \mathrm{ml}$ for 24 and $48 \mathrm{~h}$ of exposure, respectively. PE induced apoptosis and cell cycle arrest in SW480 cells as observed under electron microscopy and with flow cytometry. Apoptosis increased from 5.1 (controls) to $39.0 \%$ in $80.0 \mu \mathrm{g} / \mathrm{ml}$ PE-treated cells. Differences in protein expression were identified using proteomic techniques. Protein spots $(1018 \pm 60$ and $1010 \pm 60)$ were resolved in PE-treated and untreated group. Forty differential protein spots were analyzed with MALDI-TOF-MS, including GRP78 and NPM1. The expression as measured by qPCR and western blotting agreed with data from two-dimensional electrophoresis. GRP78, NPM1, MTHSP75, Ezrin and Annexin A2 were decreased and HSP60 was increased after PE treatment, indicating that PE may target multiple proteins to induce apoptosis.
\end{abstract}

\section{Introduction}

Colon cancer, a highly malignant tumor, is the 3rd most common cause of cancer-related death according to global epidemiological data and the prevalence is increasing in

Correspondence to: Dr Qiyu Bao, School of Laboratory Medicine and Life Science/Institute of Biomedical Informatics, Wenzhou Medical University, Wenzhou, Zhejiang 325035, P.R. China

E-mail: baoqy@genomics.cn

Dr Shengbin Li, School of Forensic Medicine, Xi'an Jiaotong University, Xi'an, Shaanxi 710000, P.R. China

E-mail: shbinlee@mail.xjtu.edu.cn

*Contributed equally

Key words: phycoerythrin, SW480 cells, apoptosis, proteomics, molecular mechanism the face of better nutrition and improved living conditions (1). Traditional therapeutic methods for treating colon cancer include surgical tumor removal, chemotherapy and radiotherapy, but these are limited by tumor recurrence and significant side-effects. Specifically, 5-year survival of hepatic metastases from large bowel carcinomas with surgical treatment is less than $30 \%$ (2), thus, better therapies or approaches are needed urgently. Investigations of signaling molecules that are expressed in tumors may be a promising avenue.

Gracilaria lemaneiformis (kelp referred to as Nostoc), is a Gracilaria species (gigartinales rhodophyta) and a rich source of polysaccharides, protein, vitamins and multiple minerals such as phosphorus, calcium, iodine, iron, zinc and magnesium (3). Phycoerythrin (PE) from G. lemaneiformis is an important light-harvesting protein with potential use in the food and drug industries with potential antioxidant, immunomodulatory, antitumor, radiation-resistant, anti-anemic and anti-aging properties as well as few side-effects (4). Chen et al (5) demonstrated that PE facilitated macrophage phagocytic activity in tumor-bearing mice and enhanced non-specific immunity. Gao et al (6) revealed that PE inhibited human breast cancer MCF-7 cells and induced apoptosis related to cell cycle arrest but the antitumor effects were complex and the molecular mechanism for this outcome remains unclear.

Genomics permits the study of tumorigenesis at the molecular level and proteomics allows a focus on expression and function of tumor proteins (7) for screening and identifying tumor biomarkers $(8,9)$, classifying tumors $(10)$, and for developing drugs as well as assessing mechanisms of oncogenesis (11). Thus, with proteomic technology and bioinformatic analysis we investigated molecular mechanisms of PE inhibition of SW480 cells and identified the proteins associated with proliferation and inhibition. These data will offer a theoretical foundation for future development of cancer therapeutics.

\section{Materials and methods}

Cell strain. The human colon cancer SW480 cell line was purchased from the Cell Bank at the Chinese Academy of 
Sciences (Shanghai, China). Cells were cultured in RPMI1640 containing $10 \%$ fetal bovine serum (FBS) in an incubator with $5.0 \% \mathrm{CO}_{2}$ at $37^{\circ} \mathrm{C}$.

Reagents. PE was extracted from fresh Gracilaria lemaneiformis (12) and the purity of PE was $5.37\left(\mathrm{~A}_{565 / 280 \mathrm{~mm}}\right)$. RPMI-1640 medium and trypsin were products of Gibco (Waltham, MA, USA). FBS was purchased from Hangzhou Chinese Holly Biotechnology Ltd. (Hangzhou, China). CCK-8 was a product of Sigma-Aldrich (St. Louis, MO, USA). An Annexin V/PI staining kit was purchased from Lianke Biotechno Co., Ltd., (Hangzhou, China). Cell culture plates were obtained from Corning Costar Corp. (Cambridge, MA, USA). Reverse transcription and PCR kits were products of Takara Biotechnology Ltd. (Dalian, China). Primary and secondary antibodies were from Beyotime Institute of Biotechnology (Shanghai, China).

CCK-8 testing inhibition of PE on SW480 growth. Cells $\left(5 \times 10^{4} / \mathrm{ml}\right)$ were inoculated into 96 -well culture plates $(100 \mu \mathrm{l}$ each well) and $24 \mathrm{~h}$ later, supernatant was removed and $\mathrm{PE}$ medium was added at 6 different concentrations $(0,5,10$, 20,40 and $80 \mu \mathrm{g} / \mathrm{ml}$ ) in sextuplicate. Cisplatin was a positive control. After incubation CCK-8 was added ( $20 \mu \mathrm{l} /$ well) for another $4 \mathrm{~h}$. Absorbance was read at $490 \mathrm{~nm}$ and $\mathrm{IC}_{50}$ values for PE were calculated $\left(\mathrm{R}=\left(\mathrm{A}_{\text {control }}-\mathrm{A}_{\text {positive }}\right) / \mathrm{A}_{\text {control }} \times 100 \%\right)$ using the Logit method.

Microscopic observation. Polylysine-preprocessed coverslips were seeded in 6 -well plates and $1.5 \mathrm{ml}$ cell suspension $\left(1.5 \times 10^{4} / \mathrm{ml}\right)$ was added to each well. Next, $24 \mathrm{~h}$ later, cells were treated with PE $(0,20,40$ and $80 \mu \mathrm{g} / \mathrm{ml})$ for $48 \mathrm{~h}$. Some samples were examined under an inverted microscope, and others were collected, rinsed three times with $0.01 \mathrm{~mol} / \mathrm{l} \mathrm{PBS}$ (pH 7.0), followed by fixation with $2.5 \%$ glutaraldehyde and $1 \%$ osmic acid. Ethanol was used for dehydration. After drying under $\mathrm{CO}_{2}$ and ion sputtering and metal spraying, samples were visualized under a scanning electron microscope (Hitachi S-3000N; Hitachi, Ltd., Tokyo, Japan) (13).

FCM measurement of apoptosis. Cells were seeded $\left(5 \times 10^{4} / \mathrm{ml}\right)$ into $25-\mathrm{ml}$ culture flasks for $24 \mathrm{~h}$ and were treated with PE at different concentrations $(0,10,20,40$ and $80 \mu \mathrm{g} / \mathrm{ml}$, respectively) for $48 \mathrm{~h}$. According to the Annexin V/PI kit instructions, primary medium was removed and pancreatin solution without EDTA was added for digestion which was terminated by adding medium. After centrifugation, $0.5 \mathrm{ml}$ PBS $(10 \mathrm{mmol} / \mathrm{l}$, $\mathrm{pH} 7.0), 10 \mathrm{ml}$ media with binding reagent, $1.25 \mu 1$ FITC $(200 \mu \mathrm{g} / \mathrm{ml})$ and $10 \mu \mathrm{l} \mathrm{PI}(50 \mu \mathrm{g} / \mathrm{ml})$ were added into each tube successively. The reaction was at room temperature and in the dark for 10 min and flow cytometry (BD Biosciences, San Jose, CA USA) was used to measure cells and data were analyzed using WinMDI 3.0 (14). All experiments were performed in triplicate.

FCM cell cycle determination. Cell samples were prepared and analyzed as described above. Cells treated with PE for $48 \mathrm{~h}$ were collected and fixed with pre-cooled $70 \%$ ethanol overnight at $4^{\circ} \mathrm{C}$ and washed with $0.01 \mathrm{~mol} / 1$ PBS three times. After permeabilization, cells were treated with RNAse (final concentration, $10 \mu \mathrm{g} / \mathrm{ml}$ ) for $1 \mathrm{~h}$ at $37^{\circ} \mathrm{C}$ and then stained with PI (final concentration, $50 \mu \mathrm{g} / \mathrm{ml}$ ). The reaction was incubated at $37^{\circ} \mathrm{C}$ in the dark for $30 \mathrm{~min}$ and flow cytometry was used to measure cell cycle arrest. Data were analyzed using BD FACSDiva software (14). All experiments were repeated three times.

Proteomics for analyzing protein. Cell lysis buffer (200 $\mu 1$, $7 \mathrm{~mol} / \mathrm{l}$ Urea, $2 \mathrm{~mol} / 1$ thiourea, 14\% CHAPS, $40 \mathrm{mmol} / \mathrm{l}$ Tris, $65 \mathrm{mmol} / \mathrm{l}$ DTT, $5 \mathrm{mmol} / \mathrm{l} \mathrm{PMSF}, 1 \mathrm{mg} / \mathrm{ml}$ DNaseI and $0.25 \mathrm{mg} / \mathrm{ml}$ RNase A) was added to $1.5 \times 10^{6}$ cells and incubated for 30 min with intermittent swirling. The solution was centrifuged at $15,000 \mathrm{rpm}$ for $30 \mathrm{~min}$ at $4^{\circ} \mathrm{C}$ and supernatant was collected. Total protein was quantified with a BCA protein assay kit (15) and stored at $-80^{\circ} \mathrm{C}$.

First-dimension of analysis with isoelectric focusing electrophoresis was used on $200 \mu \mathrm{g}$ samples mixed with loading buffer ( $7 \mathrm{~mol} / \mathrm{l}$ urea, $2 \mathrm{~mol} / \mathrm{l}$ thiourea, $4 \%$ CHAPS, $65 \mathrm{mmol} / \mathrm{l}$ DTT, $0.2 \%$ BioLyte and $0.001 \%$ bromophenol blue). IPG glue solid state strips were used as carriers. The maximum current was $60 \mu \mathrm{A} / \mathrm{IPG}$ strip, which were hydrated and focused at $20^{\circ} \mathrm{C}$. Isoelectric focusing was performed under $8,000 \mathrm{~V}$ (total voltage-time of $30,000 \mathrm{Vh}$ ). Focused tapes were put into equilibration buffer ( $6 \mathrm{~mol} / \mathrm{l}$ urea, $2 \% \mathrm{SDS}, 50 \mathrm{mmol} / 1$ Tris-HCl, pH 8.8 and 20\% glycerol) containing 1\% DTT and $4 \%$ iodoacetamide for $15 \mathrm{~min}$. Then, tapes were transferred to $12 \%$ PAGE covered with agarose. $2 \mathrm{D}$ analysis SDS-PAGE was electrophoresed. The current $(10 \mathrm{~mA} / \mathrm{gel})$ was maintained for $15 \mathrm{~min}$ and increased to $30 \mathrm{~mA} / \mathrm{gel}$ until bromophenol blue reached the bottom. After silver staining (16), GS-800 transmission and scans were used to collect and analyze gel images (resolution 63.5x63.5). For protein identification by MS, protein dot matching was performed between analytical silver stained gels and preparative gels to correlate the precise spot position to be excised. Protein spots were compared by image-matching analysis using PDQuest 7.4.0.

Mass spectrum identification of differential protein spots. Differential spots were excised from gels and placed into 1.5-ml tubes, washed with Milli-Q water three times followed by addition of destaining solution $(15 \mathrm{mmol} / \mathrm{l}$ potassium ferricyanide and $50 \mathrm{mmol} / \mathrm{l}$ sodium thiosulfate were premixed at a volume ratio of 1:1) and samples were incubated for $20 \mathrm{~min}$. After two additional washes with Milli-Q water, pellets were immersed in acetonitrile and dehydrated. Acetonitrile was discarded and trypsin digestion $(12.5 \mathrm{mg} / 1$, performed with $20 \mathrm{mmol} / \mathrm{l}$ ammonium bicarbonate) was added and incubated at $4^{\circ} \mathrm{C}$. Then the gel was kept at $37^{\circ} \mathrm{C}$ for $18 \mathrm{~h}$ for enzymatic hydrolysis. Enzymatic reaction liquid was collected and the gel was washed with $0.1 \%$ TFA $/ 50 \%$ acetonitrile mixture twice with slight agitation to extract peptide fragments. Extraction liquid was dried under nitrogen and redissolved in $0.7 \mu \mathrm{l}$ $5.0 \mathrm{~g} / \mathrm{l} \mathrm{CHCA}$ matrix (dissolved in 50\% acetonitrile and $0.1 \%$ TFA). Samples were loaded on a stainless steel 192-well target plate and air-dried. Peptide mass fingerprints were obtained with MALDI-TOF-M (Bruker Daltonics, Inc., Billerica, MA, USA) and precision peaks quality was corrected according to automatic switching peaks of trypsin as an interior reference. Mass spectrometric data were retrieved using Mascot software (www.matrixscience.co.uk) in Swiss-Prot and NCBI nr 
Table I. Primer sequences and product sizes.

\begin{tabular}{|c|c|c|c|}
\hline Gene symbol & Nucleotide sequence & Product size (bp) & Temperature $\left({ }^{\circ} \mathrm{C}\right)$ \\
\hline GRP78 & $\begin{array}{l}\text { Forward: GGGCCCTGTCTTCTCAACAT } \\
\text { Reverse: GAGTCGAGCCACCAACAAGA }\end{array}$ & 210 & 59 \\
\hline$N P M 1$ & $\begin{array}{l}\text { Forward: GGAGGTGGTAGCAAGGTTCC } \\
\text { Reverse: GATTTCTTCACTGGCGCTTTT }\end{array}$ & 149 & 60 \\
\hline Annexin A2 & $\begin{array}{l}\text { Forward: GGACGCGAGATAAGGTCCTG } \\
\text { Reverse: GCTTTCTGGTAGTCGCCCTT }\end{array}$ & 145 & 59 \\
\hline Ezrin & $\begin{array}{l}\text { Forward: CGCTCTAAGGGTTCTGCTCTG } \\
\text { Reverse: TTGGTTTCGGCATTTTCGGT }\end{array}$ & 114 & 60 \\
\hline HSP6O & $\begin{array}{l}\text { Forward: ACAAGAACATTGGAGCTAAACTTGT } \\
\text { Reverse: TTGGCTATAGAGCGTGCCAG }\end{array}$ & 104 & 59 \\
\hline MTHSP75 & $\begin{array}{l}\text { Forward: AGGGAGCTCCTGGCTAGAAA } \\
\text { Reverse: GCCAGAACTTCCAGAGCCTT }\end{array}$ & 144 & 59 \\
\hline$p 53$ & $\begin{array}{l}\text { Forward: GAGCACTGCCCAACAACAC } \\
\text { Reverse: ATGGCGGGAGGTAGACTGA }\end{array}$ & 224 & 58 \\
\hline Caspase-3 & $\begin{array}{l}\text { Forward: ATGGAAGCGAATCAATGGAC } \\
\text { Reverse: ATCACGCATCAATTCCACAA }\end{array}$ & 242 & 56 \\
\hline Caspase-9 & $\begin{array}{l}\text { Forward: GCGAACTAACAGGCAAGCA } \\
\text { Reverse: CCAAATCCTCCAGAACCAAT }\end{array}$ & 144 & 58 \\
\hline Bcl-2 & $\begin{array}{l}\text { Forward: GTGGAGGAGCTCTTCAGGGA } \\
\text { Reverse: AGGCACCCAGGGTGATGCAA }\end{array}$ & 304 & 56 \\
\hline$\beta$-actin & $\begin{array}{l}\text { Forward: CTTCCAGCCTTCCTTCCTGG } \\
\text { Reverse: CTGTGTTGGCGTACAGGTCT }\end{array}$ & 110 & 60 \\
\hline
\end{tabular}

database (retrieval parameters: trypsin digestion, permissible error $\pm 0.2 \mathrm{Da}$, oxidative modification of methionine, iodoacetamide modification of cysteine) (17).

qPCR technique identifying $m R N A$ expression of differential proteins. The primer sets (Table I) were designed for amplification of $\beta$-actin and the expressed genes using the Premier 5.0 software and synthesized by Shanghai Sunny Biological Technology Co, Ltd. (Shanghai, China). Total RNA was extracted from PE-treated and untreated SW480 cells with Dnase I by RNase-Free Dnase Set (Qiagen, Hilden, Germany). cDNA was obtained by reverse transcription using PrimeScript RT-PCR kit (Takara). SYBR-Green I-based qPCR was performed according to routine protocols (18) using the ABI StepOnePlus Real-Time PCR system (Applied Biosystems, Carlsbad, CA, USA) and three replicates were performed for all genes in each sample. Relative changes of gene expression were measured using the $2^{-\Delta \Delta \mathrm{Ct}}$ method. Relative quantification of targets in each sample was carried out using $\beta$-actin as a control.

Western blotting testing. Samples were mixed with Laemmli's loading buffer, boiled for $5 \mathrm{~min}$, and subjected to $12 \%$ SDS-PAGE at $120 \mathrm{~V}$ followed by electroblotting to nitrocellulose membrane for $2 \mathrm{~h}$ at $80 \mathrm{~V}$. Membranes were blocked for $1 \mathrm{~h}$ with $5 \%$ skim milk in TBS at room temperature and subsequently probed overnight with anti-p53, anti-caspase-3 and anti- $\beta$-actin. The membranes were rinsed and incubated with an HRP-conjugated secondary antibody. Following the secondary antibody incubation, the membranes were rinsed and bound antibodies were detected using enhanced chemiluminescence according to the manufacturer's instructions. The protein bands were quantified by densitometry analysis.

Statistical methods. The SPSS 16.0 software was used to carry out statistical analysis and data are means \pm SD. A Student's $\mathrm{t}$-test was used to assess differences which were considered statistically significant at $\mathrm{P}<0.05$.

\section{Results}

PE inhibits SW480 cell growth. PE inhibited SW480 cell growth in a dose- and time-dependent manner (Fig. 1A). In addition, $\mathrm{IC}_{50}$ values of $\mathrm{PE}$ for 24 and $48 \mathrm{~h}$ of exposures were 48.2 and $27.4 \mu \mathrm{g} / \mathrm{ml}$, respectively. PE inhibited cell growth at $80 \mu \mathrm{g} / \mathrm{ml}$ for $24 \mathrm{~h}$ and data for beyond $48 \mathrm{~h}$ with $40 \mu \mathrm{g} / \mathrm{ml}$ were similar to those of positive controls (Fig. 1B).

Morphological effect of PE on SW480 cells. Microscopic data indicate that control SW480 cells had spindle shapes, adhered to the cell wall and tight junctions and were partially overlapped. Nuclei were large and the nucleolus was clear and dark. Increasing PE concentration caused cell shrinkage, loosening of cell junctions and some cell detachment and floating. In 

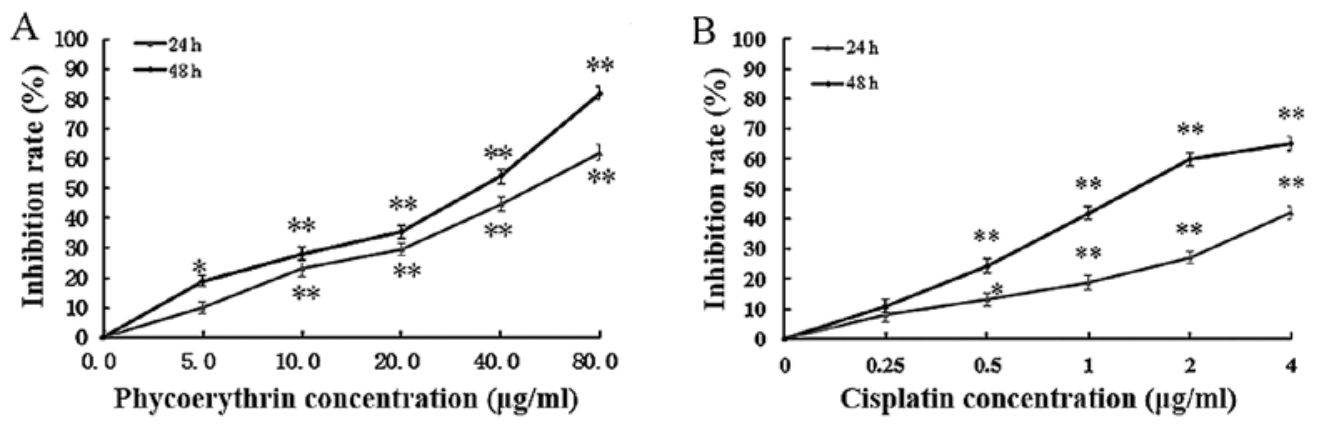

Figure 1. Inhibitory effects of PE on SW480 cell growth.

A1

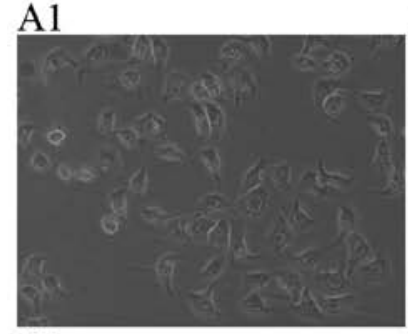

B1

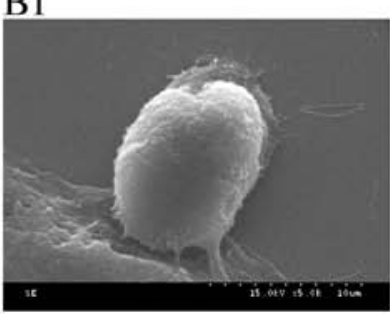

A2

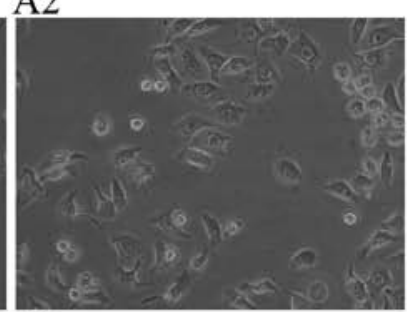

B2

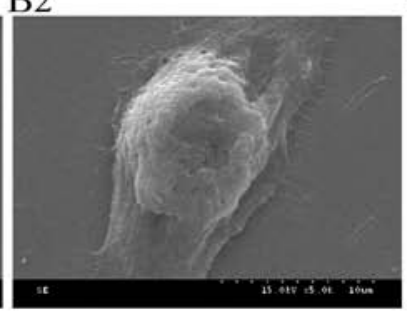

$\mathrm{A} 3$

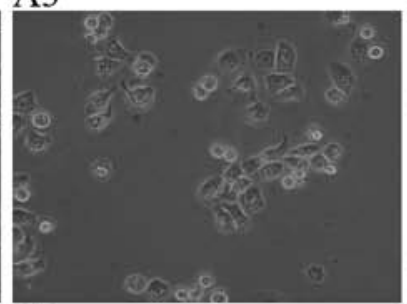

B3

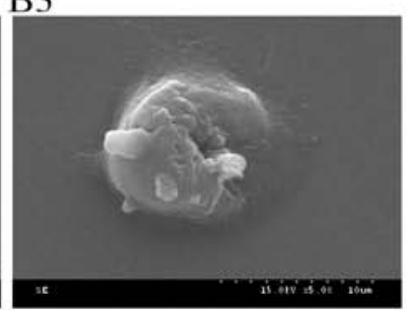

A4

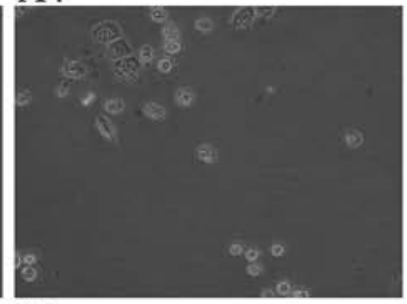

B4

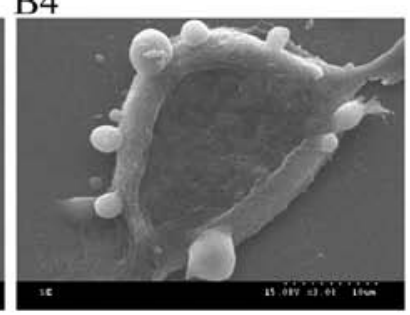

Figure 2. Morphological changes in SW480 cells treated with PE. (A1-A4) Inverted microscope (magnification, x20); (B1-B4) scanning electron microscope (R, x5,000); (1-4) 0, 20, 40 and $80 \mu \mathrm{g} / \mathrm{ml}$ PE for $48 \mathrm{~h}$.
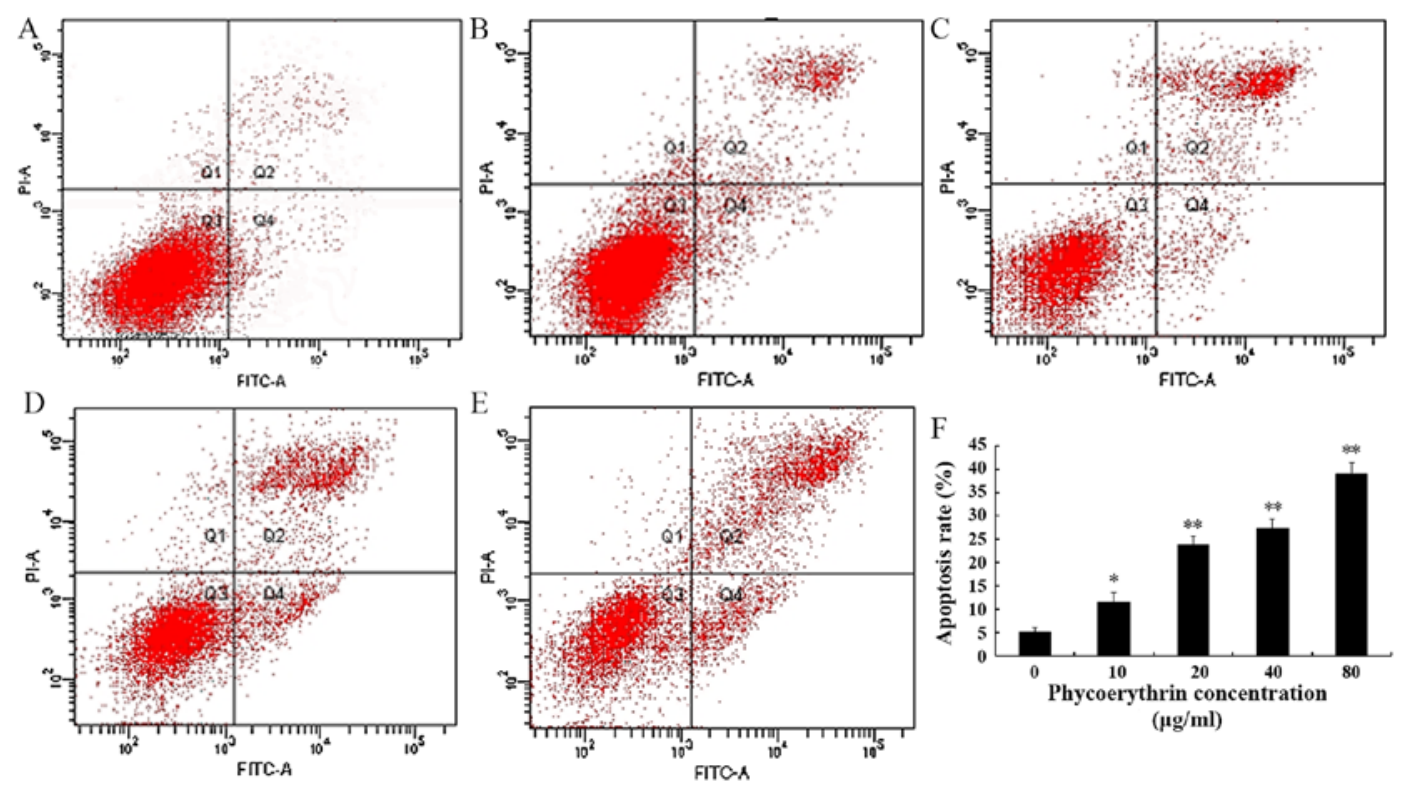

Figure 3. Effects of PE on SW480 cell apoptosis. (A-E) 0, 10, 20, 40 and $80 \mu \mathrm{g} / \mathrm{ml}$ PE for $48 \mathrm{~h}$. (F) Histogram of percent apoptotic cells from A-E. Values are means \pm SD of three measurements. ${ }^{*} \mathrm{P}<0.05,{ }^{* *} \mathrm{P}<0.01$ a significant difference between control and PE groups, as analyzed by the Student's $\mathrm{t}$-test).

addition, nuclei were shrunk and some were broken (Fig. 2A). Control SW480 cells had denser and bigger microvilli on the surface, radially stretching outward and regularly arranged as observed under a scanning electron microscope. Increasing 

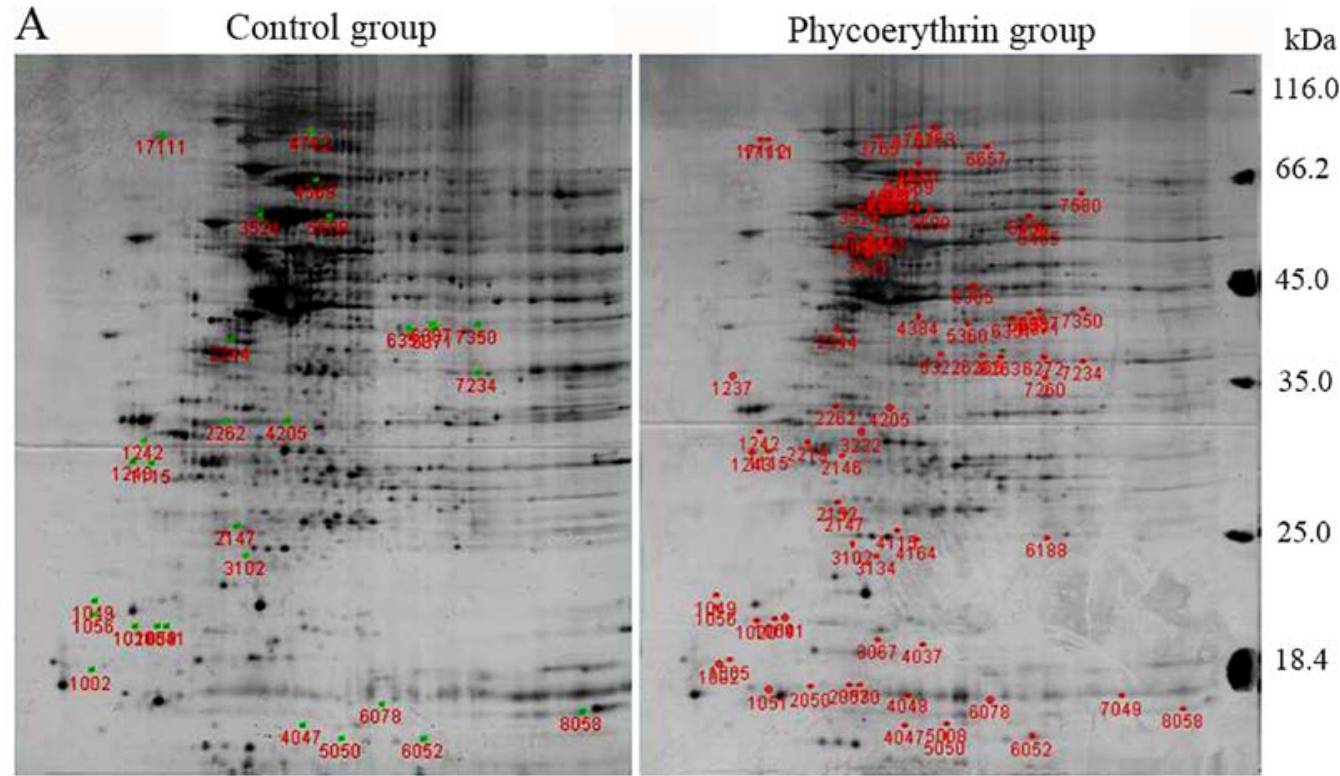

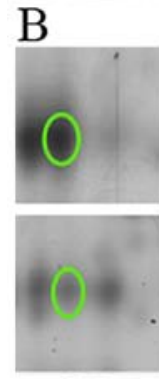

6075

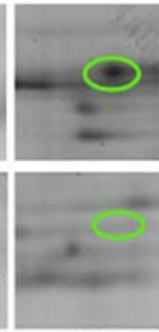

8287

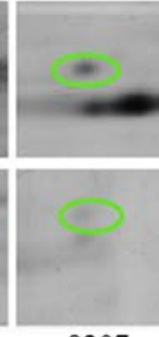

9207

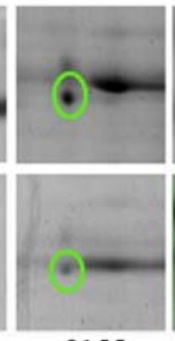

8155

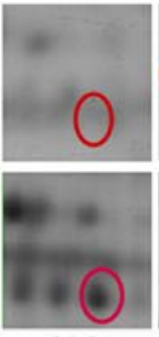

3254

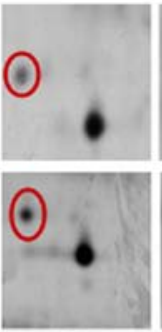

1020

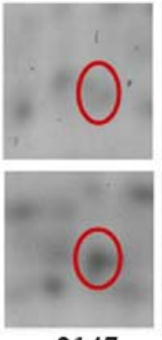

2147

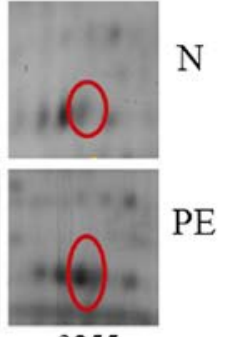

3255

Figure 4. Representative 2-DE images of proteins after PE treatment. (A) 2-DE GE of total proteins from SW480 cells; control group $(0 \mu \mathrm{g} / \mathrm{ml} \mathrm{PE}$ for $48 \mathrm{~h}), \mathrm{PE}$ group $(40.0 \mu \mathrm{g} / \mathrm{ml} \mathrm{PE}$ for $48 \mathrm{~h}$ ); (B) enlargement of gel protein spots.

Table II. Effect of PE on SW480 cell cycle.

\begin{tabular}{lccc}
\hline Group & $\mathrm{G}_{0} / \mathrm{G}_{1}(\%)$ & $\mathrm{S}(\%)$ & $\mathrm{G}_{2} / \mathrm{M}(\%)$ \\
\hline Control & $91.04 \pm 0.03$ & $8.83 \pm 0.05$ & $0.13 \pm 0.03$ \\
$10 \mu \mathrm{g} / \mathrm{ml} \mathrm{PE}$ & $69.45 \pm 0.04$ & $22.92 \pm 0.04$ & $7.63 \pm 0.06^{\mathrm{a}}$ \\
$20 \mu \mathrm{g} / \mathrm{ml} \mathrm{PE}$ & $69.52 \pm 0.05$ & $20.06 \pm 0.09$ & $10.41 \pm 0.12^{\mathrm{a}}$ \\
$40 \mu \mathrm{g} / \mathrm{ml} \mathrm{PE}$ & $66.34 \pm 0.04$ & $20.20 \pm 0.08$ & $13.46 \pm 0.12^{\mathrm{a}}$ \\
$80 \mu \mathrm{g} / \mathrm{ml} \mathrm{PE}$ & $47.66 \pm 0.07$ & $23.39 \pm 0.06$ & $28.95 \pm 0.09^{\mathrm{b}}$ \\
\hline
\end{tabular}

${ }^{\mathrm{a}} \mathrm{P}<0.05$; ${ }^{\mathrm{b}} \mathrm{P}<0.01$ indicates a significant difference between the control and $\mathrm{PE}$ groups.

PE concentrations caused shortening of microvilli and cell morphology was abnormal and damaged. After treatment with $40 \mu \mathrm{g} / \mathrm{ml}$ PE cell shrinkage was obvious, and many apoptotic bodies budded from the cell membrane (Fig. 2B).

PE-induced apoptosis in SW480 cells. The results of the Annexin V-FITC/PI staining showed that, with the increase of the PE concentration, the apoptosis rate correspondingly increased (Fig. 3). The early stage apoptosis rate increased from 3.8 to $29.0 \%$ while in the later stage it increased from 3.3 to $10.0 \%$.
PE affects cell cycle distribution in SW480 cells. After PE treatment for $48 \mathrm{~h}, \mathrm{FCM}$ was used to analyze the cell cycle. Table II shows that most cells were arrested in the $G_{0} / G_{1}$ phase and cells were arrested in the $\mathrm{S}$ stage in controls. PE treatment increased cells arrested in $\mathrm{G}_{2} / \mathrm{M}$ phases. Flow cytometry confirmed that $\mathrm{PE}$ induced $\mathrm{G}_{2} / \mathrm{M}$ cell cycle arrest in SW480 cells and this was concentration-dependent. PE-induced apoptosis may be related to cell cycle inhibition at $\mathrm{G}_{2} / \mathrm{M}$ stages.

$D E$ atlas analysis. Total proteins of control and PE-treated group were subjected to $2 \mathrm{DE}$ analysis and data show that 3 gels from controls generated an average of $1010 \pm 60$ protein dots whereas 3 gels from the treatment group had $1018 \pm 60$ dots and matching score was $99 \%$. Comparing two groups of proteins with expression that was 2-fold more or less were consistent with the data from the gels and these proteins were selected for additional analysis. A total of 379 proteins were identified (Fig. 4A), including 188 upregulated and 191 downregulated proteins. Of these 40 protein dots were chosen for MS analysis (Fig. 4B). Fifteen of their positive protein spots (Table III) are implicated in apoptosis, oxidative stress, lipid and ion transport and tumor cell growth. To validate the MS data, qPCR and western blotting were used to analyze effects of PE on the expression of GRP78, MTHSP75, HSP60, NPM1, Ezrin, Annexin A2, p53, caspase-3 and Bcl-2 (Figs. 5 and 6). Compared with controls, differences were statistically 
Table III. Protein spot data identified by MS.

\begin{tabular}{rrllrrrrrr}
\hline No. & Spot no. & Match to & \multicolumn{1}{c}{ Protein } & $\begin{array}{c}\text { Relative } \\
\text { expression }\end{array}$ & Match & $\begin{array}{l}\text { Sequence } \\
\text { coverage }\end{array}$ & Score & PI & Mr \\
\hline 1 & 2655 & gil16507237 & $\begin{array}{l}\text { 78 kDa glucose-regulated protein } \\
\text { precursor (GRP78) }\end{array}$ & $\downarrow$ & $396(328)$ & $53 \%$ & 8355 & 5.07 & 72402 \\
& & & & & & & & \\
2 & 2531 & gil21961605 & Keratin 10 & $\downarrow$ & $27(16)$ & $36 \%$ & 536 & 5.09 & 59020 \\
3 & 3330 & gil10835063 & Nucleophosmin isoform 1 (NPM1) & $\downarrow$ & $68(49)$ & $37 \%$ & 1645 & 4.64 & 32726 \\
4 & 4373 & gil119607256 & hCG1988300, isoform CRA_a & $\downarrow$ & $98(89)$ & $41 \%$ & 2895 & 5.09 & 47241 \\
5 & 4485 & gil181573 & Cytokeratin 8 (CK8) & $\downarrow$ & $266(226)$ & $59 \%$ & 5414 & 5.52 & 53529 \\
6 & 5164 & gil1568551 & Histone (H2B) & $\downarrow$ & $27(53)$ & $26 \%$ & 1555 & 10.31 & 13928 \\
7 & 6082 & gil435476 & Cytokeratin 9 & $\downarrow$ & $32(28)$ & $17 \%$ & 926 & 5.19 & 62320 \\
8 & 6302 & gil4757756 & Annexin A2 isoform 2 & $\downarrow$ & $104(87)$ & $61 \%$ & 2523 & 7.57 & 38808 \\
9 & 6379 & gil28317 & Unnamed protein product & $\downarrow$ & $19(18)$ & $4 \%$ & 648 & 5.17 & 59720 \\
10 & 6658 & gil21614499 & Ezrin & $\downarrow$ & $152(98)$ & $41 \%$ & 1920 & 5.94 & 69484 \\
11 & 17111 & gil182855 & 80K-H protein & $\uparrow$ & $21(21)$ & $8 \%$ & 320 & 4.34 & 60228 \\
12 & 3524 & gil31542947 & 60 kDa heat shock protein, & $\uparrow$ & $123(107)$ & $46 \%$ & 3440 & 5.7 & 61187 \\
& & & mitochondrial HSP60 & & & & & \\
13 & 4762 & gil292059 & MTHSP75 & $\downarrow$ & $167(138)$ & $58 \%$ & 3974 & 5.97 & 74019 \\
14 & 2344 & gil306875 & C protein & $\uparrow$ & $87(70)$ & $28 \%$ & 2315 & 5.1 & 32004 \\
15 & 1041 & gil7331218 & Keratin 1 & $\uparrow$ & $16(16)$ & 0.05 & 453 & 8.16 & 66149 \\
\hline
\end{tabular}
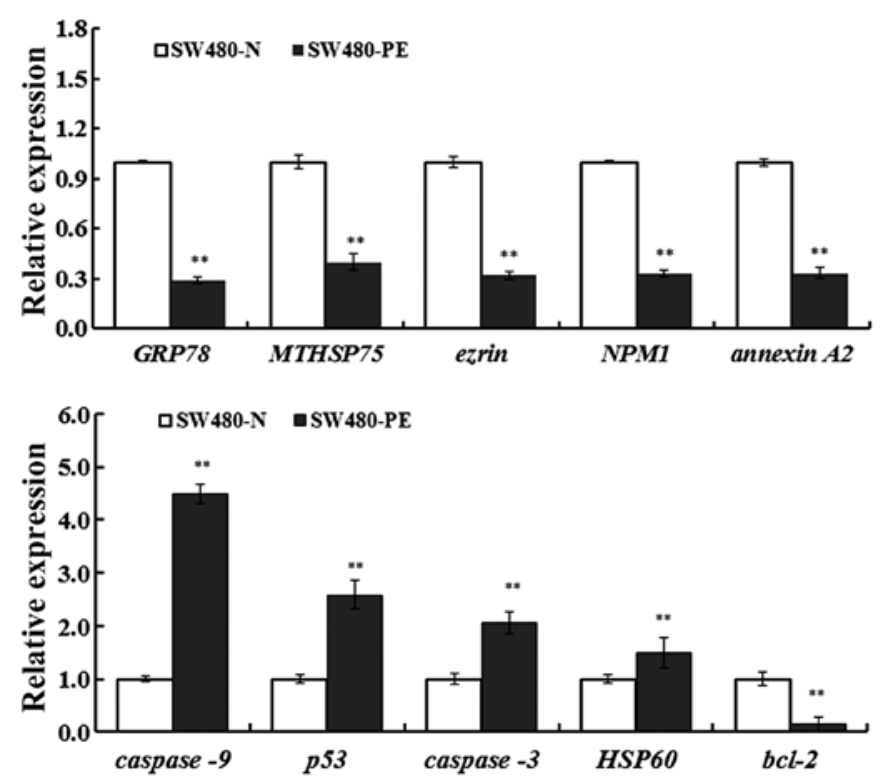

Figure 5. Effects of PE on gene expression in SW480 cells. Values are means \pm SD of three measurements. ${ }^{*} \mathrm{P}<0.05,{ }^{* *} \mathrm{P}<0.01$ a significant difference between the control and PE groups, as analyzed by the Student's t-test).

significant $(\mathrm{P}<0.05$ or $\mathrm{P}<0.01)$ and these data agreed with protein analyses.

\section{Discussion}

PE, a phycobiliprotein found in plants such as red alga and G. lemaneiformis, is the product of covalent binding of apoprotein and an open-chain tetrapyrrole chromophore via the formation of thioether and it fluoresces orange (19).
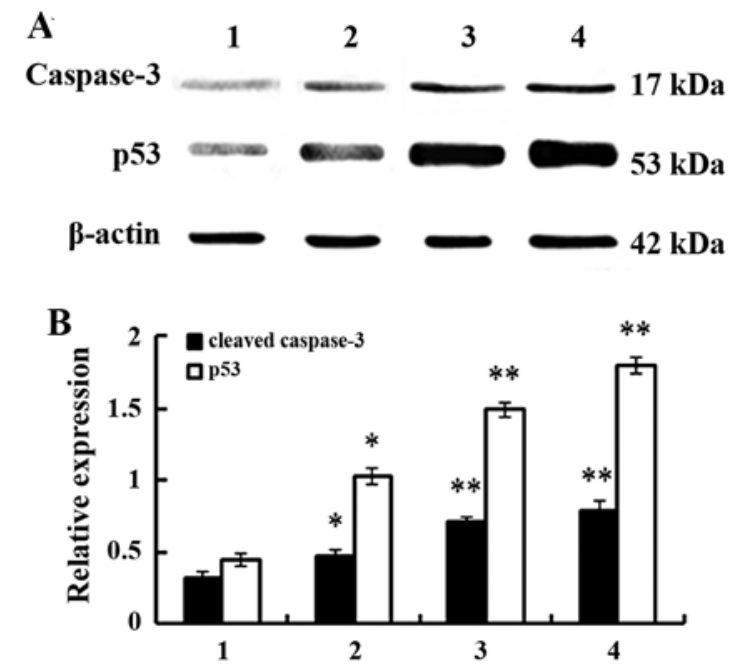

Figure 6 (A and B). Western blots of differentially expressed proteins ( $\mathrm{p} 53$ and caspase-3). Values are means $\pm \mathrm{SD}$ of three measurements. ${ }^{*} \mathrm{P}<0.05$, ${ }^{* *} \mathrm{P}<0.01$ significant difference between control and $\mathrm{PE}$ groups, as analyzed by the Student's t-test).

Its antitumor effects are of interest for treating tumors as a photosensitizer or a fluorescent probe but few studies suggest any direct cancer inhibition (20). Recent reports of antitumor effects of PE indicate that PE significantly suppresses growth of human cervical cancer HeLa cells and this is dose-dependent. With PE treatment, HeLa cells were arrested at the $\mathrm{G}_{2} / \mathrm{M}$ phase and cell proliferation was inhibited and apoptosis occurred (21) but how this happened was unclear. Previous studies suggest that PE induced cell apoptosis perhaps by reducing mitochondrial membrane potentials and damaging their integrity (22), 
which was essential for live cancer cells. Also, PE caused cell cycle arrest and apoptosis by upregulating expression of cyclin dependent kinase CDC25A which increased cyclin at $\mathrm{G}_{1}$ and $\mathrm{S}$ stages and indirectly downregulated its binding protein, CDK2 (23). With proteomics, we screened and identified 15 proteins related to PE inhibition of colon cancer, including metabolism- and apoptosis-related proteins, a cytoskeletal and a carrier protein and another protein of unknown function. Thus, 6 proliferation-associated protein proteins had modified expression and most were related to apoptosis, or signal pathway interference.

Heat shock proteins (HSPs) have highly conserved structures and are common to all biological cells as they participate in cell growth and metabolism. HSPs exist as HSP70, 90, 60 and micromolecular HSP (24). Among the Hsp70 family are cytoplasmic HSP70, mitochondria HSP75 and endoplasmic reticulum (ER) glucose regulatory protein GRP78 or immune globulin heavy chain binding protein, which can promote correct protein folding to maintain normal ER function of and interaction with enzyme 1 (IRE1), PKR-like ER kinase (PERK) and activating transcription factor 6 (ATF6) to turn on/ER stress for tumor cells to escape stress-induced apoptosis. Also, GRP78 may upregulate expression of anti-apoptotic molecule Bc1-2 within the nucleus to bind with caspase- 7 and caspase-12 in the cytoplasm to prevent ER stress and subsequent cell cascades (25). GRP78 was reported to be critical to tumor cell growth by inhibiting expression of fibrosarcoma cells and constraining tumor formation in animals. Neuroglioma cells proliferate well when GRP78 is highly expressed. When the GRP78 gene was knocked out (26), cancer cell apoptosis was accelerated via induction of ER stress. Dong et al (27) reported that GRP78 facilitated tumor growth by improving proliferation and the anti-apoptotic ability of cancer cells. MTHSP75 is a chaperone located in mitochondria that helps regulate biological functions including cell survival, proliferation, chondriosome synthesis and transfer of intracellular protein (28). MTHSP75 decreases cell damage by regulating opening of the mitochondrial permeability transition pore (29) and high expression of HSP75 may enhance anti-apoptotic capacities and motility of cancer cells and cause cell proliferation and transfer. Chen and Hang (30) observed changes in tumor growth and transfer ability using siRNA to silence HSP75 in a human osteosarcoma cell line and reported that this decreased cancer cell growth and transference. In most apoptotic systems, Hsp60 can be released from the mitochondria and aggregate cytoplasmically and enhance apoptosis. Cell death was also induced by active substance BMD188. Hsp60 accelerated caspase maturity and activation of caspase-3 (31). In the marrow stromal HS-5 cell line, HSP60 could activate caspase- 3 and caspase- 9 but not caspase- 8 , prompting release of mitochondrial cytochrome $c$ to the cytoplasm, causing apoptosis (32). In the present study, we found that SW480 cells underwent cell cycle arrest and increased apoptosis after PE treatment and that GRP78, mtHSP75 and HSP60 were downregulated, indicating similar functions.

NPM (or B23, NO38 and nurnatri), is a multifunctional phosphorylated shuttle protein (33) important to various physiological and pathological processes including centrosome duplication, ribosome synthesis, DNA repair, molecular chaperone and stress response caused by stimulants in vitro and in vivo. Previous studies confirmed that downregulation of mRNA of NPM slowed cell cycle progression and mitosis, and induced apoptosis and this may occur via p53 inhibition (34). After UV radiation cells were damaged and NPM reset the nucleoplasm and regulated p53 and HDM2. By binding to HDM2, NPM negatively regulated HDM2-p53 and stabilized p53 (35). Colombo et al (36) demonstrated that NPM interacted with p53 after stress and the p53 enhanced function may be attributable to transcriptional activity of downstream factor p21 to inhibit tumorigenesis. When NPM siRNA transfected A431 cells were tested, cell proliferation decreased and stopped at the S stage, and fewer cells were in the mitotic phase, inhibiting cell growth (37). NPM1 in SW480 cells was down-regulated significantly after PE treatment and was similar to NPM1 silencing: SW480 cell growth was reduced indicating that NPM1 may be a target of PE to inhibit tumorigenesis.

Ezrin, the coding gene of vli2, as a member of the ezrin-radixin-moesin (ERM) family is a membrane cytoskeletal cross-linker protein involved in cell interaction and cell matrices via regulation of actin, controlling cellular morphology, adjusting cell adhesion molecules, signal transduction and engulfing tumor cells (38). Ezrin has a significant role in the development, infiltration and transfer of tumor cells. Localized to a specific membrane area, ezrin combines with membrane proteins (such as CD44, CD95 and ICAM-2) and scaffolding proteins (such as E3KARR and EBP50) to activate the membrane cytoskeletal chain via signal transduction. Also, tyrosine phosphorylation sites on ezrin, when linked to PIP2, are activated and polar-oriented (39). As a receptor of tyrosine kinase, ezrin can intracellularly signal to control cell proliferation and differentiation after a particular tyrosine kinase phosphorylation. Decreasing expression of ezrin protein inhibits cell proliferation and cells in metaphase cells decrease (40). Also, a significant reduction of cellular pseudopod formation and their migration and invasiveness was reduced. Ezrin may do this through many pathways, but specifics are not known. Similarly, in SW480 cells, PE can reduce the expression of ezrin which could be the target spot of inhibiting proliferation of colon cancer cells.

Annexin A2 (ANXA2), a calcium-dependent phospholipid binding protein, is widely distributed in eukaryotic cell membranes, the cytoplasm and extracellular media, accounting for up to $0.5-2.0 \%$ of total cell protein (41). It mainly participates in membrane transportation and in activities dependent on membrane calmodulin such as membrane fusion of exocytosis, vesicle trafficking, cell adhesion, proliferation, apoptosis, DNA replication, signal transduction and ion channel formation $(42,43)$. Reports suggest that highly expressed ANXA2 in human colorectal cancer tissues/cells may be a diagnostic marker as well as a target for treatment and tumor prognosis (44). Here, ANXA2 in SW480 control cells were more highly expressed than cells treated with PE which inhibited proliferation and induced apoptosis and this likely occurred via regulation of the epidermal growth factor receptor signal transduction pathway with phosphorylation of tyrosin residues that signal through the Ras and PI3K pathways to control nuclear target gene expression (45). In addition, ANXA2 may regulate expression of several apoptosis-related proteins (such as caspase-3, p53, or Bc1-2; Figs. 5 and 6) to 
block apoptosis-related pathways (46). Given the essential role in intracellular information conduction, ANXA2 may be an essential therapeutic target for tumor therapy by inhibiting its expression or eliminating its influence on signaling pathway.

In conclusion, SW480 treated with PE underwent significant changes in expression of various proteins that may serve as related targets for PE-inhibition of tumors in vitro. HSP, NPM1, Ezrin and Annexin A2 expression were upregulated or downregulated by PE and had antitumor effects by influencing cell apoptosis, proliferation and energy metabolism. This is a novel theory for further study the mechanism of action at a protein level and verification and functional analysis of these proteins requires further study.

\section{Acknowledgements}

The present study was supported by the National Natural Science Foundation of China (nos. 30571009 and 81501808) the Natural Science Foundation of Zhejiang Province, China (Z307471 and LQ17H160015) and the Science and Technology Foundation of Zhejiang Province, China (2009C33040).

\section{References}

1. Bullard Dunn K: Retrorectal tumors. Surg Clin North Am 90: 163-171, 2010. Table of Contents. doi: 10.1016/j.suc.2009.09.009.

2. Seitz U, Bohnacker S, Seewald S, Thonke F, Brand B, Bräiutigam $\mathrm{T}$ and Soehendra N: Is endoscopic polypectomy an adequate therapy for malignant colorectal adenomas? Presentation of 114 patients and review of the literature. Dis Colon Rectum 47: 1789-1796, discussion 1796-1787, 2004.

3. Zhang GR: Determination of seven trace elements in Gracilaria Lemaneiformis by atomic absorption spectrometry. Chin $\mathrm{J}$ Spectrosc Lab 24: 1005-1008, 2007.

4. Li BH, Xie SS and Lu ZK: Spectral properties of new photosensitizers for photodynamic diagnosis and therapy. Guang Pu Xue Yu Guang Pu Fen Xi 22: 902-904, 2002 (In Chinese).

5. Chen MZ, Du H and Xu BJ: Gracilaria phycoerythrin influence on H-22 tumor immune function in mice. Chin Tradit Herbal Drugs 42: 1329-1332, 2010.

6. Gao SY, Wang J and Ji YB: Study on phycoerythrin induces MCF-7 apoptosis by controlling variation of $\Delta \Psi \_\mathrm{m}$. J Harbin University of Commerce 28: 8-13, 2012.

7. He QY and Chiu JF: Proteomics in biomarker discovery and drug development. J Cell Biochem 89: 868-886, 2003.

8. Seliger B and Kellner R: Design of proteome-based studies in combination with serology for the identification of biomarkers and novel targets. Proteomics 2: 1641-1651, 2002.

9. Srinivas PR, Verma M, Zhao Y and Srivastava S: Proteomics for cancer biomarker discovery. Clin Chem 48: 1160-1169, 2002.

10. Alaiya AA, Franzén B, Hagman A, Silfverswärd C, Moberger B, Linder S and Auer G: Classification of human ovarian tumors using multivariate data analysis of polypeptide expression patterns. Int J Cancer 86: 731-736, 2000.

11. Utleg AG, Yi EC, Xie T, Shannon P, White JT, Goodlett DR, Hood L and Lin B: Proteomic analysis of human prostasomes. Prostate 56: 150-161, 2003.

12. Liu LN, Chen XL, Zhang XY, Zhang YZ and Zhou BC: One-step chromatography method for efficient separation and purification of R-phycoerythrin from Polysiphonia urceolata. J Biotechnol 116: 91-100, 2005.

13. Jaganathan SK, Supriyanto E and Mandal M: Events associated with apoptotic effect of p-Coumaric acid in HCT-15 colon cancer cells. World J Gastroenterol 19: 7726-7734, 2013.

14. Lu W, Yu P and Li J: Induction of apoptosis in human colon carcinoma COLO 205 cells by the recombinant $\alpha$ subunit of C-phycocyanin. Biotechnol Lett 33: 637-644, 2011.

15. Saini MK, Sanyal SN and Vaiphei K: Piroxicam and C-phycocyanin mediated apoptosis in 1,2-dimethylhydrazine dihydrochloride induced colon carcinogenesis: Exploring the mitochondrial pathway. Nutr Cancer 64: 409-418, 2012.
16. Görg A, Obermaier C, Boguth G, Harder A, Scheibe B, Wildgruber $\mathrm{R}$ and Weiss W: The current state of twodimensional electrophoresis with immobilized $\mathrm{pH}$ gradients. Electrophoresis 21: 1037-1053, 2000.

17. Li C, Tan YX, Zhou H, Ding SJ, Li SJ, Ma DJ, Man XB, Hong Y, Zhang L, Li L, et al: Proteomic analysis of hepatitis B virusassociated hepatocellular carcinoma: Identification of potential tumor markers. Proteomics 5: 1125-1139, 2005.

18. Wang H, Yang Y, Chen W, Ding L, Li P, Zhao X, Wang X, Li A and Bao Q: Identification of differentially expressed proteins of Arthrospira (Spirulina) plantensis-YZ under salt-stress conditions by proteomics and qRT-PCR analysis. Proteome Sci 11: 6, 2013.

19. Bermejo R, Acién FG, Ibáñez MJ, Fernández JM, Molina E and Alvarez-Pez JM: Preparative purification of B-phycoerythrin from the microalga Porphyridium cruentum by expanded-bed adsorption chromatography. J Chromatogr B Analyt Technol Biomed Life Sci 790: 317-325, 2003.

20. Huang B, Wang GC and Li ZG: Antitumor studies of C-phycocyanin chromophore peptides mediated photodynamic therapy. Acta Laser Biology Sinica 11: 194-198, 2002.

21. Morcos NC, Berns M and Henry WL: Phycocyanin: Laser activation, cytotoxic effects, and uptake in human atherosclerotic plaque. Lasers Surg Med 8: 10-17, 1988.

22. Phillips D: Chemical mechanisms in phothodynamic therapywith Phthal ocyanines. Prog Reaction Kinet 22: 175-300, 1997.

23. Xu BH: Study on the apoptosis induced by phycoerythrin through cell cycle in human breast cancer MCF-7. D Harbin University of Commerce 33-34, 2010.

24. Joo M, Chi JG and Lee H: Expressions of HSP70 and HSP27 in hepatocellular carcinoma. J Korean Med Sci 20: 829-834, 2005.

25. Suzuki T, Lu J, Zahed M, Kita K and Suzuki N: Reduction of GRP78 expression with siRNA activates unfolded protein response leading to apoptosis in HeLa cells. Arch Biochem Biophys 468: 1-14, 2007.

26. Rauschert N, Brändlein S, Holzinger E, Hensel F, MüllerHermelink HK and Vollmers HP: A new tumor-specific variant of GRP78 as target for antibody-based therapy. Lab Invest 88: 375-386, 2008.

27. Dong D, Stapleton C, Luo B, Xiong S, Ye W, Zhang Y, Jhaveri N, Zhu G, Ye R, Liu Z, et al: A critical role for GRP78/BiP in the tumor microenvironment for neovascularization during tumor growth and metastasis. Cancer Res 71: 2848-2857, 2011.

28. Hua G, Zhang Q and Fan Z: Heat shock protein 75 (TRAP1) antagonizes reactive oxygen species generation and protects cells from granzyme M-mediated apoptosis. J Biol Chem 282: 20553-20560, 2007.

29. Xiang F, Huang YS, Shi XH and Zhang Q: Mitochondrial chaperone tumour necrosis factor receptor-associated protein 1 protects cardiomyocytes from hypoxic injury by regulating mitochondrial permeability transition pore opening. FEBS J 277 : 1929-1938, 2010.

30. Chen JH and Hang W: Effects of HSP75 small interfering RNA on cell proliferation and migration in human osteosarcoma cell line U2-OS. J China Med Univ 42: 1145-1147, 2013.

31. Chandra D, Choy G and Tang DG: Cytosolic accumulation of HSP60 during apoptosis with or without apparent mitochondrial release: Evidence that its pro-apoptotic or pro-survival functions involve differential interactions with caspase-3. J Biol Chem 282: 31289-31301, 2007.

32. Kim YS, Koh JM, Lee YS, Kim BJ, Lee SH, Lee KU and Kim GS: Increased circulating heat shock protein 60 induced by menopause, stimulates apoptosis of osteoblast-lineage cells via up-regulation of toll-like receptors. Bone 45: 68-76, 2009.

33. Grisendi S, Mecucci C, Falini B and Pandolfi PP: Nucleophosmin and cancer. Nat Rev Cancer 6: 493-505, 2006.

34. Chen D, Yoon JB and Gu W: Reactivating the ARF-p53 axis in AML cells by targeting ULF. Cell Cycle 9: 2946-2951, 2010.

35. Kurki S, Peltonen K, Latonen L, Kiviharju TM, Ojala PM, Meek D and Laiho M: Nucleolar protein NPM interacts with HDM2 and protects tumor suppressor protein p53 from HDM2mediated degradation. Cancer Cell 5: 465-475, 2004.

36. Colombo E, Marine JC, Danovi D, Falini B and Pelicci PG: Nucleophosmin regulates the stability and transcriptional activity of p53. Nat Cell Biol 4: 529-533, 2002.

37. Chen JH and Hang W: Effects of regulating NPM on the proliferative activity of human SCC A431 cells. Soochow University: 18-22, 2013. 
38. Jonstrup SP, Koch J and Kjems J: A microRNA detection system based on padlock probes and rolling circle amplification. RNA 12: 1747-1752, 2006.

39. Fais S, De Milito A and Lozupone F: The role of FAS to ezrin association in FAS-mediated apoptosis. Apoptosis 10: 941-947, 2005.

40. Lozupone F, Lugini L, Matarrese P, Luciani F, Federici C, Iessi E, Margutti P, Stassi G, Malorni W and Fais S: Identification and relevance of the CD95-binding domain in the $\mathrm{N}$-terminal region of ezrin. J Biol Chem 279: 9199-9207, 2004.

41. Lokman NA, Ween MP, Oehler MK and Ricciardelli C: The role of annexin A2 in tumorigenesis and cancer progression. Cancer Microenviron 4: 199-208, 2011.
42. Fatimathas L and Moss SE: Annexins as disease modifiers. Histol Histopathol 25: 527-532, 2010.

43. Zhang X, Liu S, Guo C, Zong J and Sun MZ: The association of annexin A2 and cancers. Clin Transl Oncol 14: 634-640, 2012.

44. Duncan R, Carpenter B, Main LC, Telfer C and Murray GI Characterisation and protein expression profiling of annexins in colorectal cancer. Br J Cancer 98: 426-433, 2008.

45. Grewal T and Enrich C: Annexins - modulators of EGF receptor signalling and trafficking. Cell Signal 21: 847-858, 2009.

46. Huang Y, Jin Y, Yan CH, Yu Y, Bai J, Chen F, Zhao YZ and Fu SB: Involvement of Annexin A2 in p53 induced apoptosis in lung cancer. Mol Cell Biochem 309: 117-123, 2008. 